\section{Isolation of Aphidicolin as a Root Growth Inhibitor from Harziella entomophilla}

\author{
Kazushige Kawada, Yasuo Kimura, \\ Kazumasa Katagiri, * Akinori SUzUKI \\ and Saburo TAMURA
}

\section{Department of Agricultural Chemistry, The University of Tokyo, Bunkyo-ku, Tokyo \\ *Devision of Forest Protection, Forestry and Forest Products Research Institute, Ushiku, Ibaraki}

Received April 18, 1978

In the course of our screening research for new plant growth regulators among metabolites of microorganisms, we noticed the presence of a root growth inhibitor of lettuce and rice seedlings in the culture broth of Harziella entomophila Ishiwata and Miyake. Then we attempted the isolation of the active principle and succeeded in the isolation of it as aphidicolin, I. In this paper we wish to report the isolation and identification of aphidicolin contained in the culture filtrate of the fungus as well as the biological activities of this compound.

The fungus was cultured stationarily in the CzapekDox medium containing $2.0 \%$ yeast extract for 25 days at $26^{\circ} \mathrm{C}$. The culture broth thus obtained was filtered and the filtrate was extracted three times with ethyl acetate at pH 2.0. The combined extracts were washed with sodium bicarbonate solution and water, successively. After drying over anhydrous sodium sulfate, the extract was evaporated in vacuo. The residual syrup was applied onto a silica gel column (Wacogel C-200), which was eluted with benzene-ethyl acetate-methanol.

In the bioassay using lettuce and rice seedlings, marked inhibitory activity on the root growth was observed in an eluate with $100 \%$ ethyl acetate.

The crude solid, which was obtained on evaporation of the solvent, was recrystallized from ethyl acetatemethanol to give $I$ as colorless needles melting at $242.0 \sim 242.5^{\circ} \mathrm{C}$, in a yield of $8 \mathrm{mg}$ from 1 liter of culture filtrate. After double development, I showed a single spot at $R f 0.48$ and 0.38 on each plate (silica gel $G F_{254}$ ) developed with ethyl acetate- $n$-hexane-methanol $(15: 2: 1, v / v)$ and benzene-acetone $(1: 1, v / v)$, respectively, and the spot was visualized by spraying with $50 \%$ sulfuric acid.

The molecular formula, $\mathrm{C}_{20} \mathrm{H}_{34} \mathrm{O}_{4}$ was assigned to this compound through mass spectrometry $[\mathrm{m} / \mathrm{e}: 307$ $\left(\mathrm{M}^{+}-\mathrm{CH}_{2} \mathrm{OH}\right)$, TMS derivative $\left.m / e: 626\left(\mathrm{M}^{+}\right)\right]$and elemental analysis (Anal. Found: C, $71.17 ; \mathrm{H}, 10.03$; O, 19.17. Calcd. for $\mathrm{C}_{20} \mathrm{H}_{34} \mathrm{O}_{4}: \mathrm{C}, 70.97 ; \mathrm{H}, 10.12$;
$0,18.91 \%) . \quad[\alpha]_{\mathrm{D}}^{23}+10.0(c=2.1, \mathrm{MeOH})$. IR $\nu_{\mathrm{max}}^{\mathrm{Nujo}}$ $\mathrm{cm}^{-1}: 3520,3440,3360,1077,1047,1027$. PMR $\delta_{\text {TMS }}^{\text {Pyrine-ds }}$ ppm: $0.76(3 \mathrm{H}, \mathrm{s}), 0.98(3 \mathrm{H}, \mathrm{s}), 1.2 \sim 3.0(\mathrm{ca}$. $20 \mathrm{H}$, br.m), 3.70 (5H, br.), $5.60(1 \mathrm{H}$, br.), $5.84(1 \mathrm{H}$, br. $)$, $6.08\left(1 \mathrm{H}\right.$, br.) CMR ppm (Pyridine-d $\left.\mathrm{d}_{s}\right): 15.4(\mathrm{q}), 18.0$ (q), 23.5(t), 25.4(t), 27.2(t), 27.3(t), 27.3(t), $29.0(\mathrm{t})$, $31.7(\mathrm{t}), 33.3(\mathrm{t}), 34.0(\mathrm{~d}), 40.1(\mathrm{~s}), 40.5(\mathrm{~d}), 40.9(\mathrm{~s})$, 42.0 (d), $49.6(\mathrm{~s}), 63.3(\mathrm{t}), 71.8(\mathrm{t}), 74.2(\mathrm{~d}), 76.3(\mathrm{~s})$.

On treatment with acetic anhydride in pyridine, I gave a triacetylated derivative (II) as crystalls, followed by recrystallization from ethyl acetate- $n$-hexane. Mp $149.0 \sim$ $150.0^{\circ} \mathrm{C}$. IR $\nu_{\max }^{\mathrm{Nujol}} \mathrm{cm}^{-1}: 3520,1743,1720,1276,1249$ 1043. PMR $\delta_{\mathrm{TMS}}^{\mathrm{CDCl}_{3}} \mathrm{ppm}: 1.00(6 \mathrm{H}, \mathrm{s}), 1.98(6 \mathrm{H}, \mathrm{s})$ $2.06(3 \mathrm{H}, \mathrm{s}), 3.74(1 \mathrm{H}, \mathrm{d}, J=8.0 \mathrm{~Hz}), 3.98(1 \mathrm{H}, \mathrm{d}, J=$ $8.0 \mathrm{~Hz}), 3.95(2 \mathrm{H}, \mathrm{s}), 4.80(1 \mathrm{H}, \mathrm{m})$. MS $m / e: 464\left(\mathrm{M}^{+}\right)$ $391\left(\mathrm{M}^{+}-\mathrm{CH}_{2} \mathrm{OOCCH}_{3}\right)$.

The bis-acetonide derivative III was prepared by treatment of I with dimethoxypropane and $p$-toluene sulfonic acid for $24 \mathrm{hr}$ at room temperature. Physicochemical properties of III recrystallized from methanol are as follows. $\mathrm{C}_{28} \mathrm{H}_{48} \mathrm{O}_{4}\left(\mathrm{M}^{+}\right.$418). $\mathrm{Mp} 140.0 \sim$ $142.0^{\circ} \mathrm{C} . \quad$ IR $\nu_{\mathrm{max}}^{\mathrm{Nujol}} \mathrm{cm}^{-1}: 1204,1099,1060,874$ PMR $\delta_{\text {TMS }}^{\text {Pridine } d_{5}} \mathrm{ppm}: 0.70(3 \mathrm{H}, \mathrm{s}), 0.96(3 \mathrm{H}, \mathrm{s}), 1.38$ $(6 \mathrm{H}, \mathrm{s}), 1.20 \sim 2.32$ (ca. $30 \mathrm{H}, \mathrm{br}$ ), $3.19(1 \mathrm{H}, \mathrm{d}, J=12.0$ $\mathrm{Hz}), 3.51(1 \mathrm{H}, \mathrm{d}, J=8.0 \mathrm{~Hz}), 3.52(1 \mathrm{H}, \mathrm{m}), 3.59(1 \mathrm{H}$, d, $J=12.0 \mathrm{~Hz}), 3.71(1 \mathrm{H}, \mathrm{d}, J=8.0 \mathrm{~Hz})$.

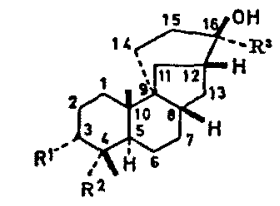

$$
\begin{aligned}
& \text { I; } R^{1}=\mathrm{OH}, \mathrm{R}^{2}=\mathrm{R}^{3}=\mathrm{CH}_{2} \mathrm{OH} \\
& \text { II; } R^{1}=O \mathrm{OAC}, \mathrm{R}^{2}=\mathrm{R}^{3}=\mathrm{CH}_{2} \mathrm{OAC}
\end{aligned}
$$

III

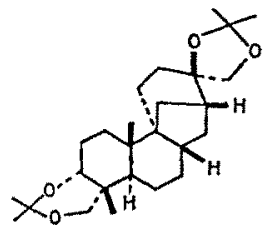

From these data mentioned above, I was seemed to be aphidicolin, an antimitotic and antiviral tetrahydroxy diterpene from Cephalosporium aphidicola Petch $^{1 /}$ and Nigrospora sphaerica (Sacc.). ${ }^{2)}$ Its identity was established by direct comparison of III with an authentic specimen of aphidicolin bis-acetonide ${ }^{3)}$ which was kindly sent by Dr. B. Hesp. The two were indistingushable on a silica gel TLC and no depression in melting point was observed upon admixture. Moreover, physico-chemical data of III were identical with those of authentic bis-acetonide. Thus, I was determined to be aphidicolin.

I scarcely influenced the shoot growth of lettuce and rice seedlings. However, it markedly inhibited the root growth as shown in Fig. 1. At a dose of $20 \mathrm{mg} /$ liter, the root growth of lettuce seedlings was suppressed to $50 \%$. For the root growth of rice seedlings, I inhi- 


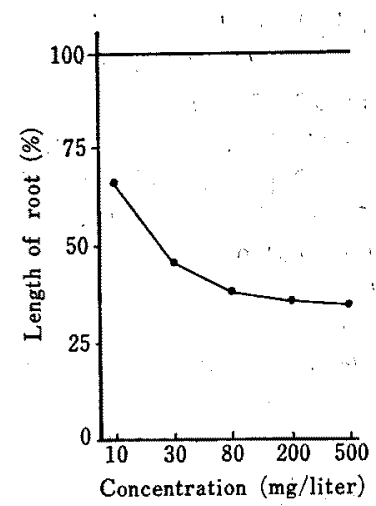

FIG. 1. Effect of Aphidicolin on the Growth of Lettuce Seedlings.

Control length: $12.3 \mathrm{~mm}$.

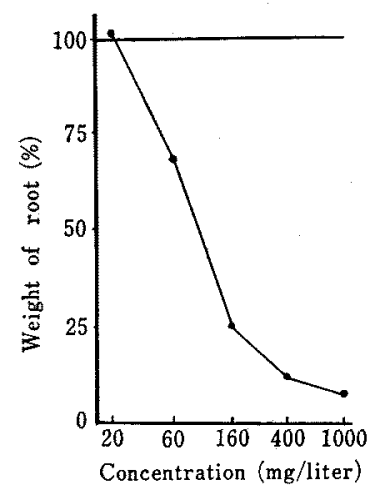

FIG. 2. Effect of Aphidicolin on the Growth of Rice Seedlings.

Control fresh weight: $11.6 \mathrm{~g}$.

bited at a dose of $100 \mathrm{mg} /$ liter to $50 \%$ and at a dose of $400 \mathrm{mg} /$ liter the root growth was scarcely observed.

Further, biological activity of I was examined using avena coleoptile segments. I alone did not affect the straight growth of segments at dosages of $0.1 \sim 300 \mathrm{mg}$ /

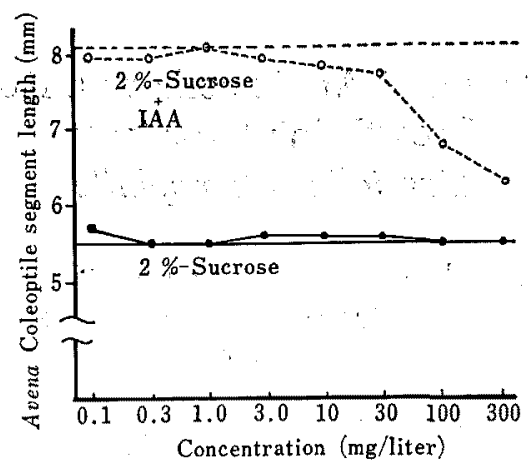

FIG. 3. Effect of Aphidicolin on the Growth of Avena Coleoptile Segments.

Control length: with IAA $(0.3 \mathrm{mg} / \mathrm{liter}), 8.1 \mathrm{~mm}$, --- without IAA, $5.5 \mathrm{~mm}$,

liter. However, when applied with IAA at $0.3 \mathrm{mg} / \mathrm{liter}$, I interfered the stimulative effect of IAA on the segments at a dose of $30 \mathrm{mg} /$ liter.

Since aphidicolin is known as a potent inhibitor of cellular deoxyribonucleic acid synthesis of cultured human embryonic lung cells, ${ }^{4)}$ the root growth of lettuce and rice seedlings may be attributable to the inhibition of DNA synthesis.

This report seems to be the first one to show that aphidicolin possesses inhibitory activity on the plant growth.

\section{REFERENCES}

1) K. M. Braundret, W. Dalziel, B. Hesp, J. A. J. Jarvis and S. Neidle, J. Chem. Soc. D, 1972, 1027.

2) A. N. Starratt and S. R. Loschiavo, Can. J. Microbiol., 20, 416 (1974).

3) W. Dalziel, B. Hesp and K. M. Stevenson, J. Chem. Soc., Perkin Trans. 1, 1973, 2841.

4) R. A. Bucknall, H. Moores, R. Simms and B. Hesp, Antimicrob. Agents Chemother., 4, 294 (1973). 